\title{
Structural features discriminate androgen receptor N/C terminal and coactivator interactions
}

\author{
Emily B. Askew ${ }^{+}$, John T. Minges, Andrew T. Hnat, and Elizabeth M. Wilson* \\ Curriculum in Toxicology, Laboratories for Reproductive Biology, Lineberger Comprehensive \\ Cancer Center, and the Departments of Pediatrics, and Biochemistry and Biophysics, University \\ of North Carolina, Chapel Hill, North Carolina 27599-7500 USA
}

\begin{abstract}
Human androgen receptor (AR) transcriptional activity involves interdomain and coactivator interactions with the agonist-bound AR ligand binding domain (LBD). Structural determinants of the $\mathrm{AR} \mathrm{NH}_{2}$ - and carboxyl-terminal interaction between the $\mathrm{AR} \mathrm{NH}_{2}$-terminal $\mathrm{FXXLF}$ motif and activation function 2 (AF2) in the LBD were shown previously by crystallography. In this report, we provide evidence for a region in AR LBD helix 12 outside the AF2 binding cleft that facilitates interactions with the FXXLF and LXXLL motifs. Mutagenesis of glutamine 902 to alanine in AR LBD helix 12 (Q902A) disrupted AR FXXLF motif binding to AF2, but enhanced coactivator LXXLL motif binding. Functional compensation for defective FXXLF motif binding by ARQ902A was suggested by the slower dissociation rate of bound androgen. Functional importance of glutamine 902 was indicated by the charged residue germline mutation Q902R that caused partial androgen insensitivity, and a similar somatic mutation Q902K reported in prostate cancer, both of which increased the androgen dissociation rate and decreased AR transcriptional activity. High affinity equilibrium androgen binding was retained by alanine substitution mutations at Tyr-739 in AR LBD helix 5 or Lys-905 in helix 12 structurally adjacent to AF2, whereas transcriptional activity decreased and the androgen dissociation increased. Deleterious effects of these loss of function mutations were rescued by the helix stabilizing AR prostate cancer somatic mutation H874Y. Sequence $\mathrm{NH}_{2}$-terminal to the AR FXXLF motif contributed to the $\mathrm{AR} \mathrm{NH}_{2}-$ and carboxyl-terminal interaction based on greater AR-2-30 FXXLF motif peptide binding to the agonist-bound AR LBD than a shorter AR-20-30 FXXLF motif peptide. We conclude that helix 12 residues outside the AF2 binding cleft modulate AR transcriptional activity by providing flexibility to accommodate FXXLF or LXXLL motif binding.
\end{abstract}

\section{Keywords}

androgen receptor; N/C interaction; FXXLF motif; LXXLL motif; androgen insensitivity; prostate cancer

\footnotetext{
(C) 2011 Elsevier Ireland Ltd. All rights reserved.

*Corresponding author: EM Wilson, Laboratories for Reproductive Biology, University of North Carolina at Chapel Hill, NC 27599-7500 USA, TEL 919-966-5168, FAX 919-966-2203.

+Present address: Department of Anatomy and Cell Biology, East Carolina University Brody School of Medicine, Greenville, North Carolina, USA

Publisher's Disclaimer: This is a PDF file of an unedited manuscript that has been accepted for publication. As a service to our customers we are providing this early version of the manuscript. The manuscript will undergo copyediting, typesetting, and review of the resulting proof before it is published in its final citable form. Please note that during the production process errors may be discovered which could affect the content, and all legal disclaimers that apply to the journal pertain.

Conflict of interest

The authors have declared that no conflict of interest exists.
} 


\section{Introduction}

The androgen receptor (AR) is a ligand-dependent transcription factor that regulates androgen-dependent gene transcription by binding androgen response element DNA and interacting with coregulatory proteins and transcription factors. AR transcriptional activity requires the unstructured $\mathrm{NH}_{2}$-terminal activation function 1 (Simental et al., 1991; Lavery et al., 2008) and the highly structured ligand binding domain (LBD) that includes the activation function 2 (AF2) hydrophobic surface for FXXLF or LXXLL motif binding (He et al., 2004). Structural stability and function of AF2 depends on AR binding of testosterone, dihydrotestosterone (DHT) or synthetic anabolic steroids (Wilson, 2007). Transcriptional activity from activation function 1 and $\mathrm{AF} 2$ is regulated by the androgen-dependent $\mathrm{NH}_{2}-$ and carboxyl-terminal (N/C) interaction between the $\mathrm{NH}_{2}$-terminal FXXLF motif and AF2 that has been extensively characterized for AR (Langley et al., 1995; He and Wilson, 2002; Wilson, 2009). An N/C interaction was also reported for the estrogen (Kraus et al., 1995), progesterone (Tetel et al., 1999) and mineralocorticoid receptors (Pippal et al., 2009), although the interaction motifs were not defined. The androgen-dependent AR N/C interaction is inhibited by the classical AR antagonists, hydroxyflutamide and casodex (Langley et al., 1995; Wilson, 2011). Similarly, the mineralocorticoid receptor N/C interaction is induced by aldosterone or the synthetic agonist $9 \alpha$-fludrocortisol, and is inhibited by deoxycorticosterone, cortisol (Pippal et al., 2009) or synthetic mineralocorticoid receptor antagonists (Murai-Takeda et al., 2010).

The AR N/C interaction mediates an intermolecular interaction (Langley et al., 1995, 1998; Schaufele et al., 2005) that is influenced by coregulatory proteins. AR regulation of androgen-dependent genes that depend on the AR N/C interaction is enhanced by p160 coactivators, such as transcriptional intermediary factor 2 (TIF2). Other AR coactivators compete with the AR N/C interaction by binding AF2 through their own FXXLF (He et al., 2002b; Hsu et al., 2003) or FXXLF-related motif (van de Wijngaart et al., 2006). The AR coregulator melanoma antigen-A11 (MAGE-11) binds the AR FXXLF motif in a competitive relationship with the N/C interaction (Bai et al., 2005) and increases AR transcriptional activity by exposing $\mathrm{AF} 2$ for coactivator recruitment and by interacting directly with p160 and p300 coactivators (Askew et al., 2009, 2010). MAGE-11 is a primate-specific steroid receptor coregulator that undergoes post-translational modulation by phosphorylation and monoubiquitinylation (Bai and Wilson, 2008), colocalizes with AR in nuclei of cells in the human male and female reproductive tracts (Bai et al., 2008), and is overexpressed in castration-recurrent prostate cancer (Karpf et al., 2009; Wilson, 2010). AR transcriptional activity mediated by the N/C interaction was reported to be enhanced by peroxisome proliferator-activated receptor $\gamma$-coactivator- $1 \alpha$ (Shiota et al., 2010), c-Jun (Bubulya et al, 2001), CBP and F-SRC-1 (Ikonen et al., 1997). Inhibition of AR transcriptional activity by interference with the AR N/C interaction has been attributed to PTEN-FoxO1 (Ma et al., 2009), p53 (Shenk et al., 2001), cyclin D1 (Burd et al., 2004) and AR corepressors.

The androgen insensitivity syndrome (AIS) is associated with partial or complete absence of male sex development caused by single amino acid mutations in the AR gene, demonstrating the functional importance of AR in male sex development and function (Quigley et al., 1995). Loss of function AR mutations that cause AIS can disrupt androgen binding or AR binding to androgen response element DNA. However, some naturally occurring AR mutants retain high affinity androgen binding and cause AIS or oligospermic infertility by interfering with the AR N/C interaction (Langley et al., 1998; He et al., 1999, 2006; Jääskeläinen et al., 2006; Ghali et al., 2003; Thompson et al., 2001; Ghadessy et al., 1999; Quigley et al., 2004). Loss of function AR mutations highlight the physiological importance of the N/C interaction in AR function. Conversely, gain of function AR mutations that occur 
with low frequency in prostate cancer may contribute to castration-recurrent growth by enhancing the AR N/C interaction (Tan et al, 1997; He et al., 2006; Askew et al., 2007). In this report, we provide biochemical evidence that AR LBD surface residues Gln-902, Tyr-739 and Lys-905 structurally adjacent to AF2 facilitate FXXLF or LXXLL motif binding.

\section{Material and methods}

\subsection{Plasmids}

Human AR expression vector pCMV-AR (Lubahn et al., 1988) and H874Y (Tan et al., 1997; He et al., 2006) and I737T mutants (He et al., 1999; Quigley et al., 2004), pCMVAR-507-919 (Simental et al., 1991) and H874Y mutant (He et al., 2006), GAL-AR-658-919 and H874Y mutant (Askew et al., 2007), GAL-AR-20-30 FXXLF motif fusion peptide (He and Wilson, 2003), pNLVP16-AR-1-660 (Langley et al., 1998), VP-TIF2.1 (VPTIF2-624-1287) (Voegel et al., 1998; He et al., 1999), and PSAEnh-Luc and 5XGAL4Luc3 reporter vectors (Askew et al., 2010) were described. pCMV-AR-Q902A, Q902R, Q902K and Y739A were created by double PCR mutagenesis and subcloning into TthIII and XbaI sites of pCMV-AR. pCMV-AR-K905A was created by double PCR mutagenesis and subcloning the amplified fragments into the Csp45I and XbaI sites of pCMV-AR. pCMVAR-H874Y,Y739A and H874Y,I737T were created by subcloning KpnI and Csp45I fragment of pCMV-AR-Y739A or pCMV5 AR-I737T into pCMV-AR-H874Y. pCMV-ARH874Y,K905A was created by double PCR mutagenesis of pCMV-H874Y and subcloning the Csp45I and XbaI fragments into pCMV-H874Y. pCMV-AR-507-919-Q902A, Q902K and Q902R were created by excising the BglII and KpnI fragments from pCMVAR mutants and self-ligating the plasmids, with translation initiation beginning at AR Met-507. GALAR-658-919-Q902A, Y739A and K905A were created by digesting pCMV-AR mutant plasmids with TthIII and XbaI and subcloning the fragments into GALO digested with the same enzymes to express a fusion protein with GAL4 DNA binding domain residues 1-147 (Finkel et al., 1993). The extended GAL-AR-2-30 FXXLF motif fusion peptide was created by PCR amplifying pCMV-AR and subcloning the fragment into EcoRI and BamHI sites of GALO. All PCR amplified regions were verified by DNA sequencing.

\subsection{AR transcription assays}

Monkey kidney CV1 cells $\left(4 \times 10^{5} / 6 \mathrm{~cm}\right.$ dish) were transfected using calcium phosphate precipitation (He et al., 2001). Human cervical carcinoma HeLa cells $\left(5 \times 10^{4}\right.$ cells/well) in 12 well plates were transfected using FuGENE 6 (Askew et al., 2007). After $24 \mathrm{~h}$ incubation at $37^{\circ} \mathrm{C}$ in serum-free medium with or without hormone, cells were lysed in $0.5 \mathrm{ml}(\mathrm{CV} 1$ cells) or $0.25 \mathrm{ml}$ (HeLa cells) buffer containing 1\% Triton X-100, 2 mM EDTA and $25 \mathrm{mM}$ Tris phosphate, $\mathrm{pH}$ 7.8. After rocking for $30 \mathrm{~min}$ at room temperature, $0.1 \mathrm{ml}$ of cell lysates were analyzed for luciferase activity using a LumistarGalaxy BMG Labtech luminometer. Data shown are the mean and standard error representative of 3 or more independent experiments.

\subsection{Ligand binding, dissociation and immunoblot analysis}

Androgen dissociation rate studies were performed in whole cell binding assays using $3 \mathrm{nM}$ $\left[1,2,4,5,6,7-{ }^{3} \mathrm{H}\right]-\mathrm{DHT}(124 \mathrm{Ci} / \mathrm{mmol}), 5 \mathrm{nM}\left[1,2,6,7-{ }^{3} \mathrm{H}\right]$-testosterone $(78.5 \mathrm{Ci} / \mathrm{mmol})$ or 5 nM $\left[{ }^{3} \mathrm{H}\right]-17 \alpha$-methytrienolone (R1881) (82 Ci/mmol) (PerkinElmer). COS cells $\left(4 \times 10^{5} /\right.$ well) in 6 well plates were transfected using DEAE-dextran with $1 \mu \mathrm{g} /$ well wild-type or mutant pCMV-AR or $2 \mu \mathrm{g} /$ well wild-type or mutant pCMV-AR-507-919 that expresses the human AR DNA binding domain and LBD (He et al., 2001, 2006; Askew et al., 2007). After a $2 \mathrm{~h}$ incubation at $37^{\circ} \mathrm{C}$, ligand dissociation was initiated by the addition of a 10,000 -fold 
excess of unlabeled testosterone or R1881. Cells were solubilized in SDS sample buffer and analyzed by scintillation counting.

Equilibrium androgen binding constants were determined in COS cell binding assays by Scatchard plot analysis. COS cells $\left(2 \times 10^{5} /\right.$ well $)$ in 12 well plates were transfected using DEAE dextran with $0.05 \mu \mathrm{g}$ wild-type or mutant $\mathrm{pCMV}-\mathrm{AR} / \mathrm{well}$. The next day cells were incubated with 0.2 up to $6 \mathrm{nM}\left[{ }^{3} \mathrm{H}\right] \mathrm{R} 1881$ for $2 \mathrm{~h}$ at $37^{\circ} \mathrm{C}$ in the absence and presence of a 100-fold molar excess of unlabeled R1881 to account for nonspecific binding (He et al., 2006).

Immunoblots were performed using COS cells $\left(2.5 \times 10^{6} / 10 \mathrm{~cm}\right.$ dish $)$ transfected with 5-10 $\mu \mathrm{g}$ DNA using DEAE dextran (He et al., 2001). The next day cells were transferred to serum-free media, and $24 \mathrm{~h}$ later harvested in lysis buffer containing $1 \%$ Nonidet P-40, $0.5 \%$ sodium deoxycholate, $0.1 \%$ SDS, $1 \mathrm{mM}$ dithiothreitol, $1 \mathrm{mM}$ phenylmethylsulfonyl fluoride and complete protein inhibitor mixture (Roche Applied Science). In some experiments, 1 $\mu \mathrm{M}$ MG132 proteosome inhibitor was added $24 \mathrm{~h}$ and again $1 \mathrm{~h}$ prior to cell harvest to stabilize the peptides and fragments. Transfer blots were probed using rabbit polyclonal antiGAL antibody (Santa Cruz Biotechnology, 1:200 dilution), AR52 antipeptide antibody (5 $\mu \mathrm{g} / \mathrm{ml}$ ) (Lubahn et al., 1988), AR32 antipeptide antibody (0.4 $\mu \mathrm{g} / \mathrm{ml}$ ) (Quarmby et al., 1990) and mouse $\beta$-actin antibody (Abcam, 1:5000 dilution). Immunodetection utilized chemiluminescence with SuperSignal West Dura Extended Duration Substrate (Pierce).

\subsection{Crystallization of AR LBD bound to AR-2-30 peptide and testosterone}

Wild-type AR-663-919 with an $\mathrm{NH}_{2}$-terminal 6 residue histidine tag and thrombin cleavage site was expressed in Escherichia coli and cocrystalized with the AR-2-30 FXXLF motif peptide in the presence of testosterone as described (Askew et al., 2007). High resolution structure indicated identical contact sites in the AR AF2 hydrophobic surface for this longer $\alpha$-helical AR-2-30 FXXLF motif peptide as a shorter AR-20-30 FXXLF motif peptide (Askew et al., 2007), with no electron density for the 2-19 amino acid residue region of the AR-2-30 FXXLF motif bound peptide.

\section{Results}

\subsection{Inhibition of AR transcriptional activity by charged residue substitutions at AR LBD helix 12 Gln-902}

The AR-Q902K germline mutation causes partial androgen insensitivity (Umar et al., 2005), whereas AR-Q902R was reported as a somatic mutation in castration-recurrent prostate cancer (Taplin et al., 1995). Both of these AR LBD helix 12 mutations of Gln-902 decreased the androgen-dependent AR N/C interaction in mammalian two hybrid assays between the GAL-AR-658-919 fusion protein of the GAL4 DNA binding domain and human AR LBD, and the VP-AR-1-660 fusion protein of the VP16 activation domain and human AR $\mathrm{NH}_{2}$ terminal and DNA binding domains (Fig. 1A, left). Disruption of the N/C interaction and AR transcriptional activity caused by mutations in the $\mathrm{AR} \mathrm{NH}_{2}$-terminal $\mathrm{FXXLF}$ motif have demonstrated the functional requirement for the androgen-dependent AR N/C interaction (He et al., 2000). AR mutations Q902K and Q902R in GAL-AR-658-919 also inhibited the interaction with VP-TIF2-624-1287, a VP16 activation domain fusion protein with the 3 LXXLL motif region of the p160 coactivator, TIF2 (Fig. 1A, right). The decreased interaction of these mutants did not result from differences in expression assayed in COS cells after incubation with MG132, a proteosome inhibitor used to stabilize the fragments (Fig. 1A, inset).

Full-length AR-Q902K and AR-Q902R were also expressed at similar levels to wild-type AR (Fig. 2A), but were transcriptionally less active in the presence of increasing 
concentrations of DHT (Fig. 2B) or testosterone (Fig. 2C) using the prostate-specific antigen reporter gene that depends on the AR N/C interaction for full activity (He et al., 2002a). The Q902K and Q902R mutations increased the dissociation rate of DHT, testosterone and R1881 up to 4 fold from full-length AR (Table 1, top panel), and from the carboxyl-terminal AR-507-919 DNA binding domain and LBD fragment (Table 1, lower panel). AR-Q902K equilibrium binding affinity for $\left[{ }^{3} \mathrm{H}\right] \mathrm{R} 1881$ was elevated as reported (Umar et al., 2005), whereas AR-Q902R equilibrium binding affinity was similar to wild-type AR (Table 1, top panel). The increased rates of androgen dissociation from AR-507-919-Q902K and -Q902R suggested structural defects by the mutations in the ligand binding pocket.

\subsection{GIn-902 facilitates FXXLF over LXXLL motif binding}

A decrease in AR FXXLF motif binding in the N/C interaction was also seen with GALAR-658-919-Q902A, in which Gln-902 was replaced by nonpolar alanine (Fig. 1A, left). However, unlike the charged residue substitution mutations Q902K and Q902R, Q902A increased GAL-AR-658-919 binding to the TIF2 LXXLL motif fragment. Selective loss of AR FXXLF motif binding by AR-Q902A was observed over a 4 log dose response range of DHT (Fig. 1B) or testosterone (not shown), whereas TIF2 LXXLL motif binding increased (Fig. 1A and 1B). The AR-H874Y prostate cancer somatic mutation (Tan et al., 1997) that stabilizes AR LBD helix interactions (Askew et al., 2007) retained FXXLF and LXXLL motif binding in the presence of DHT similar to wild-type AR (Fig. 1B).

Unlike the charged residue substitutions at Gln-902 associated with AIS and prostate cancer, transcriptional activity of AR-Q902A and AR-H874Y mutants, which were expressed at similar levels to wild-type AR (Fig. 2A), was similar to wild-type AR in the presence of DHT (Fig. 2B), but greater than wild-type AR with testosterone (Fig. 2C). Dissociation of testosterone, DHT or R1881 from full-length AR-Q902A was similar to wild-type, although the equilibrium binding constant for $\left[{ }^{3} \mathrm{H}\right] \mathrm{R} 1881$ increased (Table 1). Dissociation rates of DHT and R1881 from AR-507-919-Q902A were almost 2 fold slower than from the wildtype fragment, with no change with testosterone.

Disruption of AR FXXLF motif binding by AR AF2 site mutants that retain high affinity equilibrium androgen binding has been shown to increase the rate of androgen dissociation (Langley et al., 1998; He et al., 2000, 2001). The increased transcriptional activity of ARQ902A with testosterone and slower dissociation of bound androgen from the AR-Q902A LBD fragment (Table 1) (Askew et al., 2007) suggested that the Q902A mutation stabilizes the LBD and rescues structural defects associated with impaired AR FXXLF motif binding.

\subsection{Dependence of AR transcriptional activity on AF2 flanking surface}

The structural requirements for FXXLF or LXXLL motif binding to AF2 were investigated further based on the proximity of AR LBD helix 5 Tyr-739 and helix 12 Lys-905 to Gln-902 in helix 12 (Fig. 3), and evidence that AR-Y739D caused complete AIS (Suzuki et al., 2001). Similar to Q902A, the Y739A and K905A mutations disrupted AR FXXLF motif binding to a greater extent than binding to the TIF2 LXXLL motifs (Fig. 1C). However, although AR-Y739A and K905A were expressed at levels similar to wild-type AR (Fig. 2A) and retained high affinity equilibrium binding of $\left[{ }^{3} \mathrm{H}\right] \mathrm{R} 1881$ (Table 1), transcriptional activity by these mutants was less than wild-type AR in the presence of DHT (Fig. 2B) or testosterone (Fig. 2C). In addition, androgen dissociation rates were 2 to 4 fold faster for DHT, testosterone and R1881 from full-length AR and the AR-507-919 mutants (Table 1) as observed for ARQ902R and Q902K (Fig. 2B, 2C, Table 1). The results suggest that the extended region of helix 12 outside the AF2 binding cleft participates in AR FXXLF and coactivator LXXLL motif binding required for full AR transcriptional activity. 


\subsection{Compensatory effects of LBD stabilization}

The increased transcriptional activity of AR-Q902A and AR-H874Y, together with the slower androgen dissociation rates, suggested that stabilization of the LBD core can overcome the detrimental effects of destabilizing mutations. To investigate this further, chimeras were created between a loss of function mutation in or near helix 12 and the AR helix stabilizing mutation, H874Y. Crystal structures of AR-LBD-H874Y bound to testosterone and AR-20-30 FXXLF peptide indicated that the replacement of water-mediated hydrogen bonds with direct hydrogen bonds between interior helices 4 and 5 and exterior helix 10 increases androgen potency (Askew et al, 2007). AR-I737T was included as an AF2 site mutation that caused partial androgen insensitivity (He et al., 1999, 2006; Quigley et al., 2004).

AR is stabilized in the presence of androgen by the androgen-dependent AR N/C interaction (Kemppainen et al., 1992; He et al. 2001). AR stabilization determined on immunoblots showed that the stability of wild-type AR and Y739A and I737T mutants increased in the presence of DHT with or without the H874 mutation (Fig. 4A), whereas the stability of ARK905A increased only in the ARH874Y, K905A chimera. Transcriptional activity of ARY739A, AR-K905A and AR-I737T was rescued by introducing the H874Y mutation (Fig. 4B). The results suggest that deleterious effects of AR-K905A, Y739A or I737T loss of function mutations can be rescued by core helix stabilizing mutation $\mathrm{H} 874 \mathrm{Y}$ that promotes the AR N/C interaction and slows ligand dissociation.

\section{5. $\mathrm{NH}_{2}$-terminal ${ }^{23} \mathrm{FQNLF}^{27}$ flanking sequence contributes to the $A R \mathrm{~N} / \mathrm{C}$ interaction}

Crystal structures of the AR LBD bound to testosterone and a short $\alpha$-helical AR-20-30 FXXLF motif peptide suggested that Gln-902, Tyr-739 and Lys-905 lie in a region of the LBD that interacts with residues $\mathrm{NH}_{2}$-terminal to the AR FXXLF motif (Fig. 3) (He et al., 2004). In agreement with this, mammalian two-hybrid assays showed greater interaction of a longer GAL-AR-2-30 FXXLF motif peptide with full-length wild-type AR and AR-I737T, Y739A, Q902R and K905A mutants than the shorter GAL-AR-20-30 FXXLF motif peptide (Fig. 5). Both GAL-AR peptides were expressed at similar levels in cells incubated with the proteosome inhibitor MG132 to stabilize the peptides for detection on immunoblots (Fig. 5, inset). However, the lack of electron density in the 2-19 amino acid region in the longer AR-2-30 FXXLF motif peptide-AR LBD-testosterone crystal structure suggested that interactions between residues $\mathrm{NH}_{2}$-terminal to the AR FXXLF motif and the carboxylterminal extension of helix 12 were not sufficient to detect by crystallography.

\section{Discussion}

\subsection{AR AF2 flanking residues influence FXXLF and LXXLL motif binding}

Androgen-dependent transcriptional activity derives in part from the AR LBD AF2 region that interacts with higher affinity with the $\mathrm{AR} \mathrm{NH}_{2}$-terminal FXXLF motif (Askew et al., 2007), and depends on p160 coactivator LXXLL motif binding. Studies in this report identified a secondary interaction region structurally adjacent to the AF2 hydrophobic binding cleft that facilitates FXXLF or LXXLL motif binding and retention of bound hormone. Mutations in AR LBD helix 12 surface residues Lys-905 and helix 5 Tyr-739 disrupted FXXLF and LXXLL motif binding, even though equilibrium androgen binding affinity was maintained similar to wild-type AR. Gln-902 in helix 12 was required for AR FXXLF but not LXXLL motif binding. The slower dissociation rate of bound androgen from the AR-Q902A LBD fragment suggested that prolonged androgen retention and high affinity equilibrium androgen binding stabilizes the LBD core in a conformation that favors $\mathrm{LXXLL}$ over FXXLF motif binding. The stabilizing effects of the prostate cancer somatic mutation H874Y recovered AR transcriptional activity in the presence of loss of function 
destabilizing mutations. The studies suggest that AR LBD helix 12 Gln-902 outside the AF2 binding surface provides structural flexibility to accommodate binding of the FXXLF or LXXLL motif.

Previous studies support a secondary interaction region near the AR LBD helix 12 extension for AR FXXLF motif binding and AF2 function. The helix 12 L907F mutation outside the AF2 cleft caused complete AIS and reduced AR FXXLF motif binding, even though high affinity androgen binding was maintained (Jääskeläinen et al., 2006). Other AR LBD mutations that cause AIS and disrupt AR FXXLF motif binding without altering equilibrium androgen binding affinity include D695N prior to helix 3, R774H in helix 6, and R855H in helix 10 (Jääskeläinen et al., 2006). Within the AF2 binding cleft, so called charge clamp residues Lys-720 and Glu-897 differentiate FXXLF and LXXLL motif binding through the formation of dissimilar hydrogen bonds. Crystal structures showed that bound FXXLF or LXXLL peptides are phase shifted in the AF2 binding cleft. A hydrogen bond extends from each peptide to Lys-720, whereas only the FXXLF motif also forms a hydrogen bond to Glu-897 (He et al., 2002a, 2004, 2006; Dubbink et al., 2004). Thus, a K720A charge clamp mutation disrupts LXXLL but not FXXLF motif binding most likely because the FXXLF motif retains a hydrogen bond to Glu- 897 .

\subsection{Detrimental effects of charged residue substitutions}

Our studies highlight the potentially damaging effects of replacing nonpolar residues with charged amino acids as seen with the naturally occurring arginine (Q902R), lysine (Q902K) and aspartic acid (Y739D) substitution mutations that caused AIS or were associated with prostate cancer. Q902R and Q902K disrupted FXXLF and LXXLL motif binding and increased androgen dissociation even though equilibrium androgen binding affinity was similar to wild-type AR. In contrast, the nonpolar Q902A alanine substitution slowed the dissociation of DHT and R1881 and increased AR transcriptional activity. This suggests that replacing nonpolar residues with charged residues may impose deleterious effects on structure and function that do not necessarily reflect the true functional significance of the native residue. Such an argument might be made for the G21E mutation that implicated a role for Gly-21 in the AR N/C interaction (Callewaert et al., 2003). As suggested by our studies, inhibition of the AR N/C interaction by the G21E charged residue substitution $\mathrm{NH}_{2}-$ terminal of the FXXLF motif may result in loss of function because of structural effects imposed by the substituted charged residue. Similarly, Y739A was reported to retain high affinity equilibrium androgen binding with rapid androgen dissociation kinetics, whereas Y739D caused loss of androgen binding and complete AIS (Suzuki et al., 2001).

Evidence that residues $\mathrm{NH}_{2}$-terminal to the $\mathrm{FXXLF}$ motif interact with surface residues near AR LBD helix 12 outside the AF2 binding cleft was suggested by the greater interaction of the longer GAL-AR-2-30 FXXLF motif peptide with wild-type and mutant AR than the shorter GAL-AR-20-30 FXXLF motif peptide. The findings are in agreement with earlier studies that deletion of AR residues 3-13 from an AR-3-36 $\mathrm{NH}_{2}$-terminal fragment inhibited the N/C interaction (Steketee et al., 2002). However, crystal structure of the extended AR-2-30 FXXLF motif $\alpha$-helical peptide bound-AR LBD-testosterone complex was indistinguishable from that of the shorter AR-20-30 FXXLF motif peptide complex (He et al., 2004). This suggests that sequence $\mathrm{NH}_{2}$-terminal to the FXXLF motif forms weak interactions with the extended AR LBD helix 12 region that enhances AR transcriptional activity by facilitating FXXLF or LXXLL motif binding to AF2.

\subsection{Gain of function $A R$ mutations in prostate cancer}

One mechanism for prostate cancer progression is increased AR sensitivity to low levels of androgen and increased levels of coactivators (Gregory et al., 2001a, b). However, some 
castration-recurrent prostate cancers have naturally occurring somatic mutations in or near the AF2 site that maintain high affinity equilibrium androgen binding and transcriptional activity. Activity-enhancing AR mutations may be selectively retained during prostate cancer progression and castration-recurrent tumor growth. However, in contrast to the loss of function Q902R mutation reported in prostate cancer (Taplin et al., 1995), AR-Q902A had properties similar to the AR-H874Y somatic mutation identified in the CWR22 xenograft of human prostate cancer isolated from a hormone refractory bone marrow metastasis of a patient treated with flutamide and LHRH agonist (Tan et al., 1997) and other human prostate cancer specimens (Taplin et al., 1995). The H874Y mutation imparts DHTlike activity to testosterone by stabilizing core helix interactions (He et al., 2006; Askew et al., 2007; Lindström et al., 2010). Both ARQ902A and AR-H874Y more effectively retained bound androgen independent of the N/C interaction. The ability of H874Y to overcome the disrupting effects of destabilizing mutations in or near AR LBD helix 12 demonstrates that compensatory structural changes can enhance AR transcriptional activity.

\section{Conclusions}

An extended region in and near AR LBD helix 12 outside the AF2 binding surface provides weak interactions that discriminate AR FXXLF and coactivator LXXLL motif binding required for AR transcriptional activity.

\section{Abbreviations}
AR androgen receptor
LBD ligand binding domain
AF2 activation function 2
$\mathrm{N} / \mathrm{C} \quad \mathrm{NH}_{2}$ - and carboxyl-terminal
TIF2 transcriptional intermediary factor 2
AIS androgen insensitivity syndrome.

\section{Acknowledgments}

We thank Amanda J. Blackwelder and K. Michelle Cobb for excellent technical assistance, and Frank S. French and Robert T. Gampe for helpful discussions. The study was supported by United States Department of Defense PC073586 Fellowship Award, the Eunice Kennedy Shriver NICHD/NIH through cooperative agreement U54HD35041 as part of the Specialized Cooperative Centers Program in Reproduction and Infertility Research, US Public Health Service Grants HD16910 from NICHD, and by P01-CA77739 from the National Cancer Institute.

\section{References}

Askew EB, Bai S, Blackwelder AJ, Wilson EM. Transcriptional synergy between melanoma antigen gene protein-A11 (MAGE-11) and p300 in androgen receptor signaling. J Biol Chem. 2010; 285:21824-21836. [PubMed: 20448036]

Askew EB, Bai S, Hnat AT, Minges JT, Wilson EM. Melanoma antigen gene protein-A11 (MAGE-11) F-box links the androgen receptor $\mathrm{NH}_{2}$-terminal transactivation domain to p160 coactivators. J Biol Chem. 2009; 284:34793-34808. [PubMed: 19828458]

Askew EB, Gampe RT, Stanley TB, Faggart JL, Wilson EM. Modulation of androgen receptor activation function 2 by testosterone and dihydrotestosterone. J Biol Chem. 2007; 282:2580125816. [PubMed: 17591767]

Bai S, Grossman G, Yuan L, Lessey BA, French FS, Young SL, Wilson EM. Hormone control and expression of androgen receptor coregulator MAGE-11 in human endometrium during the window of receptivity to embryo implantation. Mol Hum Reproduction. 2008; 14:107-116. 
Bai S, He B, Wilson EM. Melanoma antigen gene protein MAGE-11 regulates androgen receptor function by modulating the interdomain interaction. Mol Cell Biol. 2005; 25:1238-1257. [PubMed: 15684378]

Bai S, Wilson EM. Epidermal growth factor-dependent phosphorylation and ubiquitinylation of MAGE-11 regulates its interaction with the androgen receptor. Mol Cell Biol. 2008; 28:1947-1963. [PubMed: 18212060]

Bubulya A, Chen SY, Fisher CJ, Zheng Z, Shen XQ, Shemshedini L. c-Jun potentiates the functional interaction between the amino and carboxyl termini of the androgen receptor. J Biol Chem. 2001; 276:44704-44711. [PubMed: 11577103]

Burd CJ, Petre CE, Moghadam H, Wilson EM, Knudsen KE. Cyclin D1 binding to the androgen receptor (AR) $\mathrm{NH}_{2}$-terminal domain inhibits activation function 2 association and reveals dual roles for AR corepression. Mol Endocrinol. 2005; 19:607-620. [PubMed: 15539430]

Callewaert L, Verrijdt G, Christiaens V, Haelens A, Claessens F. Dual function of an amino-terminal amphipatic helix in androgen receptor-mediated transactivation through specific and nonspecific response elements. J Biol Chem. 2003; 278:8212-8218. [PubMed: 12509416]

Dubbink HJ, Hersmus R, Verma CS, van der Korput HA, Berrevoets CA, van Tol J, Ziel-van der Made AC, Brinkmann AO, Pike AC, Trapman J. Distinct recognition modes of FXXLF and LXXLL motifs by the androgen receptor. Mol Endocrinol. 2004; 18:2132-2150. [PubMed: 15178743]

Finkel T, Duc J, Fearon ER, Dang CV, Tomaselli GF. Detection and modulation in vivo of helix-loophelix protein-protein interactions. J Biol Chem. 1993; 268:5-8. [PubMed: 8380166]

Ghadessy FJ, Lim J, Abdullah AA, Panet-Raymond V, Choo CK, Lumbroso R, Tut TG, Gottlieb B, Pinsky L, Trifiro MA, Yong EL. Oligospermic infertility associated with an androgen receptor mutation that disrupts interdomain and coactivator (TIF2) interactions. J Clin Invest. 1999; 103:1517-1525. [PubMed: 10359561]

Ghali SA, Gottlieb B, Lumbroso R, Beitel LK, Elhaji Y, Wu J, Pinsky L, Trifiro MA. The use of androgen receptor amino/carboxyl-terminal interaction assays to investigate androgen receptor gene mutations in subjects with varying degrees of androgen insensitivity. J Clin Endocrinol Metab. 2003; 88:2185-2193. [PubMed: 12727974]

Gregory CW, Johnson RT, Mohler JL, French FS, Wilson EM. Androgen receptor stabilization in recurrent prostate cancer is associated with hypersensitivity to low androgen. Cancer Res. 2001a; 61:2892-2898. [PubMed: 11306464]

Gregory CW, He B, Johnson RT, Ford OH, Mohler JL, French FS, Wilson EM. A mechanism for androgen receptor mediated prostate cancer recurrence after androgen deprivation therapy. Cancer Res. 2001b; 61:4315-4319. [PubMed: 11389051]

$\mathrm{He}$ B, Bowen NT, Minges JT, Wilson EM. Androgen-induced $\mathrm{NH}_{2}$ - and carboxyl-terminal interaction inhibits p160 coactivator recruitment by activation function 2. J Biol Chem. 2001; 276:4229342301. [PubMed: 11551963]

He B, Gampe RT, Hnat AT, Faggart JL, Minges JT, French FS, Wilson EM. Probing the functional link between androgen receptor coactivator and ligand binding sites in prostate cancer and androgen insensitivity. J Biol Chem. 2006; 281:6648-6663. [PubMed: 16365032]

He B, Gampe RT, Kole AJ, Hnat AT, Stanley TB, An G, Stewart EL, Kalman RI, Minges JT, Wilson EM. Structural basis for androgen receptor interdomain and coactivator interactions suggests a transition in nuclear receptor activation function dominance. Mol Cell. 2004; 16:425-438. [PubMed: 15525515]

He B, Kemppainen JA, Voegel JJ, Gronemeyer H, Wilson EM. Activation function 2 in the human androgen receptor ligand binding domain mediates interdomain communication with the $\mathrm{NH}_{2}$ terminal domain. J Biol Chem. 1999; 274:37219-37225. [PubMed: 10601285]

He B, Kemppainen JA, Wilson EM. FXXLF and WXXLF sequences mediate the $\mathrm{NH}_{2}$-terminal interaction with the ligand binding domain of the androgen receptor. J Biol Chem. 2000; 275:22986-22994. [PubMed: 10816582]

He B, Lee LW, Minges JT, Wilson EM. Dependence of selective gene activation on the androgen receptor $\mathrm{NH}_{2}$ - and carboxyl-terminal interaction. J Biol Chem. 2002a; 277:25631-25639. [PubMed: 12000757] 
He B, Minges JT, Lee LW, Wilson EM. The FXXLF motif mediates androgen receptor-specific interactions with coregulators. J Biol Chem. 2002b; 277:10226-10235. [PubMed: 11779876]

$\mathrm{He} \mathrm{B}$, Wilson EM. The $\mathrm{NH}_{2}$-terminal and carboxyl-terminal interaction in the human androgen receptor. Mol Gen Metab. 2002; 75:293-298.

He B, Wilson EM. Electrostatic modulation of steroid receptor recruitment of the LXXLL and FXXLF motifs. Mol Cell Biol. 2003; 23:2135-2150. [PubMed: 12612084]

Hsu CL, Chen YL, Yeh S, Ting HJ, Hu YC, Lin H, Wang X, Chang C. The use of phage display technique for the isolation of androgen receptor interacting peptides with $(\mathrm{F} / \mathrm{W}) \mathrm{XXL}(\mathrm{F} / \mathrm{W})$ and FXXLY new signature motifs. J Biol Chem. 2003; 278:23691-23698. [PubMed: 12714604]

Ikonen T, Palvimo JJ, Jänne OA. Interaction between the amino- and carboxyl-terminal regions of the rat androgen receptor modulates transcriptional activity and is influenced by nuclear receptor coactivators. J Biol Chem. 1997; 272:29821-29828. [PubMed: 9368054]

Jääskeläinen J, Deeb A, Schwabe JW, Mongan NP, Martin H, Hughes IA. Human androgen receptor gene ligand-binding-domain mutations leading to disrupted interaction between the $\mathrm{N}$ - and Cterminal domains. J Mol Endocrinol. 2006; 36:361-368. [PubMed: 16595706]

Karpf AR, Bai S, James SR, Mohler JL, Wilson EM. Increased expression of androgen receptor coregulator MAGE-11 in prostate cancer by DNA hypomethylation and cyclic AMP. Mol Cancer Res. 2009; 7:523-535. [PubMed: 19372581]

Kemppainen JA, Lane MV, Sar M, Wilson EM. Androgen receptor phosphorylation, turnover, nuclear transport and transcriptional activation: specificity for steroids and antihormones. J Biol Chem. 1992; 267:968-974. [PubMed: 1730684]

Kraus WL, McInerney EM, Katzenellenbogen BS. Ligand-dependent, transcriptionally productive association of the amino- and carboxyl-terminal regions of a steroid hormone nuclear receptor. Proc Natl Acad Sci USA. 1995; 92:12314-12318. [PubMed: 8618892]

Langley E, Kemppainen JA, Wilson EM. Intermolecular $\mathrm{NH}_{2}$-/carboxyl-terminal interactions in androgen receptor dimerization revealed by mutations that cause androgen insensitivity. J Biol Chem. 1998; 273:92-101. [PubMed: 9417052]

Langley E, Zhou ZX, Wilson EM. Evidence for an antiparallel orientation of the ligand activated human androgen receptor dimer. J Biol Chem. 1995; 270:29983-29990. [PubMed: 8530400]

Lavery DN, McEwan IJ. Functional characterization of the native $\mathrm{NH}_{2}$-terminal transactivation domain of the human androgen receptor: binding kinetics for interactions with TFIIF and SRC-1a. Biochemistry. 2008; 47:3352-3359. [PubMed: 18284209]

Lindström S, Ma J, Altshuler D, Giovannucci E, Riboli E, Albanes D, Allen NE, Berndt SI, Boeing H, Bueno-de-Mesquita HB, Chanock SJ, Dunning AM, Feigelson HS, Gaziano JM, Haiman CA, Hayes RB, Henderson BE, Hunter DJ, Kaaks R, Kolonel LN, Le Marchand L, Martínez C, Overvad K, Siddiq A, Stampfer M, Stattin P, Stram DO, Thun MJ, Trichopoulos D, Tumino R, Virtamo J, Weinstein SJ, Yeager M, Kraft P, Freedman ML. A large study of androgen receptor germline variants and their relation to sex hormone levels and prostate cancer risk. Results from the national cancer institute breast and prostate cancer cohort consortium. J Clin Endocrinol Metab. 2010; 95:e121-e127. [PubMed: 20534771]

Lubahn DB, Joseph DR, Sar M, Tan JA, Higgs HN, Larson RE, French FS, Wilson EM. The human androgen receptor: complementary DNA cloning, sequence analysis and gene expression in prostate. Mol Endocrinol. 1988; 2:1265-1275. [PubMed: 3216866]

Ma Q, Fu W, Li P, Nicosia SV, Jenster G, Zhang X, Bai W. FoxO1 mediates PTEN suppression of androgen receptor $\mathrm{N}$ - and $\mathrm{C}$-terminal interactions and coactivator recruitment. Mol Endocrinol. 2009; 23:213-225. [PubMed: 19074551]

Murai-Takeda A, Shibata H, Kurihara I, Kobayashi S, Yokota K, Suda N, Mitsuishi Y, Jo R, Kitagawa H, Kato S, Saruta T, Itoh H. NF-YC functions as a corepressor of agonist-bound mineralocorticoid receptor. J Biol Chem. 2010; 285:8084-8093. [PubMed: 20054001]

Pippal JB, Yao Y, Rogerson FM, Fuller PJ. Structural and functional characterization of the interdomain interaction in the mineralocorticoid receptor. Mol Endocrinol. 2009; 23:1360-1370. [PubMed: 19541744] 
Quarmby VE, Kemppainen JA, Sar M, Lubahn DB, French FS, Wilson EM. Expression of recombinant androgen receptor in cultured mammalian cells. Mol Endocrinol. 1990; 4:1399-1407. [PubMed: 2172802]

Quigley CA, De Bellis A, Marschke KB, El-Awady MK, Wilson EM, French FS. Androgen receptor defects: historical, clinical and molecular perspectives. Endocrine Rev. 1995; 16:271-321. [PubMed: 7671849]

Quigley CA, Tan JA, He B, Zhou ZX, Mebarki F, Morel Y, Forest M, Chatelain P, Ritzen EM, French FS, Wilson EM. Partial androgen insensitivity with phenotypic variation caused by androgen receptor mutations that disrupt activation function 2 and the $\mathrm{NH}_{2}$ - and carboxyl-terminal interaction. Mech Ageing Dev. 2004; 125:683-695. [PubMed: 15541764]

Schaufele F, Carbonell X, Guerbadot M, Borngraeber S, Chapman MS, Ma AA, Miner JN, Diamond MI. The structural basis of androgen receptor activation: intramolecular and intermolecular aminocarboxy interactions. Proc Natl Acad Sci USA. 2005; 102:9802-9807. [PubMed: 15994236]

Shenk JL, Fisher CJ, Chen SY, Zhou XF, Tillman K, Shemshedini L. p53 represses androgen-induced transactivation of prostate-specific antigen by disrupting hAR amino- to carboxyl-terminal interaction. J Biol Chem. 2001; 276:38472-38479. [PubMed: 11504717]

Shiota M, Yokomizo A, Tada Y, Inokuchi J, Tatsugami K, Kuroiwa K, Uchiumi T, Fujimoto N, Seki $\mathrm{N}$, Naito S. Peroxisome proliferator-activated receptor gamma coactivator-1alpha interacts with the androgen receptor (AR) and promotes prostate cancer cell growth by activating the AR. Mol Endocrinol. 2010; 24:114-127. [PubMed: 19884383]

Simental JA, Sar M, Lane MV, French FS, Wilson EM. Transcriptional activation and nuclear targeting signals of the human androgen receptor. J Biol Chem. 1991; 266:510-518. [PubMed: 1985913]

Steketee K, Berrevoets CA, Dubbink HJ, Doesburg P, Hersmus R, Brinkmann AO, Trapman J. Amino acids $3-13$ and amino acids in and flanking the 23FxxLF27 motif modulate the interaction between the $\mathrm{N}$-terminal and ligand-binding domain of the androgen receptor. Eur J Biochem. 2002; 269:5780-5791. [PubMed: 12444966]

Suzuki K, Fukabori Y, Nakazato H, Hasumi M, Matsui H, Ito K, Kurokawa K, Yamanaka H. Novel amino acid substitutional mutation, tyrosine-739-aspartic acid, in the androgen receptor gene in complete androgen insensitivity syndrome. Int J Androl. 2001; 24:183-188. [PubMed: 11380707]

Tan JA, Sharief Y, Hamil KG, Gregory CW, Zang DY, Sar M, Gumerlock PH, deVere White RW, Pretlow TG, Harris SE, Wilson EM, Mohler JL, French FS. Dehydroepiandrosterone activates mutant androgen receptors expressed in the androgen dependent human prostate cancer xenograft CWR22 and LNCaP cells. Mol Endocrinol. 1997; 11:450-459. [PubMed: 9092797]

Taplin ME, Bubley GJ, Shuster TD, Frantz ME, Spooner AE, Ogata GK, Keer HN, Balk SP. Mutation of the androgen-receptor gene in metastatic androgen-independent prostate cancer. N Engl J Med. 1995; 332:1393-1398. [PubMed: 7723794]

Tetel MJ, Giangrande PH, Leonhardt SA, McDonnell DP, Edwards DP. Hormone-dependent interaction between the amino- and carboxyl-terminal domains of progesterone receptor in vitro and in vivo. Mol Endocrinol. 1999; 13:910-924. [PubMed: 10379890]

Thompson J, Saatcioglu F, Jänne OA, Palvimo JJ. Disrupted amino- and carboxyl-terminal interactions of the androgen receptor are linked to androgen insensitivity. Mol Endocrinol. 2001; 15:923-935. [PubMed: 11376111]

Umar A, Berrevoets CA, Van NM, van Leeuwen M, Verbiest M, Kleijer WJ, Dooijes D, Grootegoed JA, Drop SL, Brinkmann AO. Functional analysis of a novel androgen receptor mutation, Q902K, in an individual with partial androgen insensitivity. J Clin Endocrinol Metab. 2005; 90:507-515. [PubMed: 15486055]

van de Wijngaart DJ, van Royen ME, Hersmus R, Pike AC, Houtsmuller AB, Jenster G, Trapman J, Dubbink HJ. Novel FXXFF and FXXMF motifs in androgen receptor cofactors mediate high affinity and specific interactions with the ligand-binding domain. J Biol Chem. 2006; 281:1940719416. [PubMed: 16690616]

Voegel JJ, Heine MJ, Tini M, Vivat V, Chambon P, Gronemeyer H. The coactivator TIF2 contains three nuclear receptor-binding motifs and mediates transactivation through CBP bindingdependent and -independent pathways. EMBO J. 1998; 17:507-519. [PubMed: 9430642] 
Wilson EM. Muscle bound? A tissue-selective nonsteroidal androgen receptor modulator. Endocrinology. 2007; 148:1-3. [PubMed: 17179140]

Wilson, EM. Functional motifs of the androgen receptor. In: Tindall, D.; Mohler, J., editors. Androgen Action in Prostate Cancer. New York: Springer; 2009. p. 241-267.

Wilson EM. Androgen receptor molecular biology and potential targets in prostate cancer. Therap Adv Urol. 2010; 2:105-117. [PubMed: 21789088]

Wilson, EM. Analysis of interdomain interactions of the androgen receptor. Chapter 8. In: Saatcioglu, F., editor. Methods in Molecular Biology: Androgen Action. Vol. 776. Humana Press, Inc.; 2011. p. 113-129. 


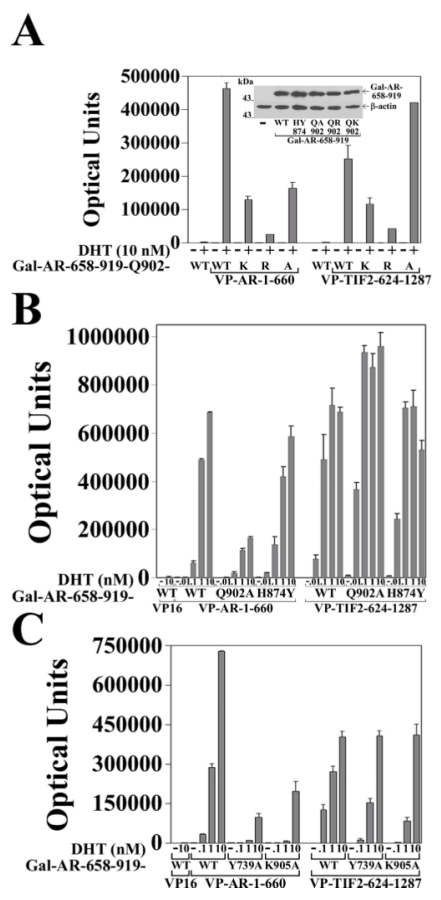

Figure 1. AR LBD helix 12 GIn-902 facilitates FXXLF motif binding to AF2

(A) HeLa cells were transfected with $0.1 \mu \mathrm{g}$ 5XGAL4Luc, $0.05 \mu \mathrm{g}$ GAL-AR-658-919 wildtype (WT), Q902K, Q902R or Q902A mutant and $0.05 \mu \mathrm{g}$ pNLVP16 empty vector, VP-

AR-1-660 or VP-TIF2-624-1287. Cells were incubated for $24 \mathrm{~h}$ in serum-free medium with and without $10 \mathrm{nM}$ DHT. (Inset) COS cells were transfected with $10 \mu \mathrm{g} \mathrm{DNA} / 10 \mathrm{~cm}$ dish of GALO empty vector (-),GAL-AR-658-919 WT, H874Y, Q902A, Q902R and Q902K mutants. Cells were incubated with $1 \mu \mathrm{M}$ MG132 for 24 and again at $1 \mathrm{~h}$ prior to harvest and $50 \mu \mathrm{g}$ protein/lane was probed using GAL and $\beta$-actin antibodies. (B) HeLa cells were transfected with $0.1 \mu \mathrm{g}$ 5XGAL4Luc3, $0.05 \mu \mathrm{g}$ GAL-AR-658-919 WT, Q902A or H874Y mutant and $0.05 \mu \mathrm{g}$ pNLVP16 empty vector (VP16), VP-AR-1-660 or VP-TIF2-624-1287. Cells were incubated for $24 \mathrm{~h}$ in serum-free medium with and without $0.01,0.1,1$ and 10 nM DHT. (C) HeLa cells were transfected with 0.1 $\mu$ g 5XGAL4Luc3, $0.05 \mu \mathrm{g}$ GALAR-658-919 WT, Y739A or K905A mutant, and $0.05 \mu \mathrm{g}$ pNLVP16 empty vector (VP16), VP-AR-1-660 or VP-TIF2-624-1287. Cells were incubated for $24 \mathrm{~h}$ in serum-free medium with and without $0.1,1$ and $10 \mathrm{nM}$ DHT. 


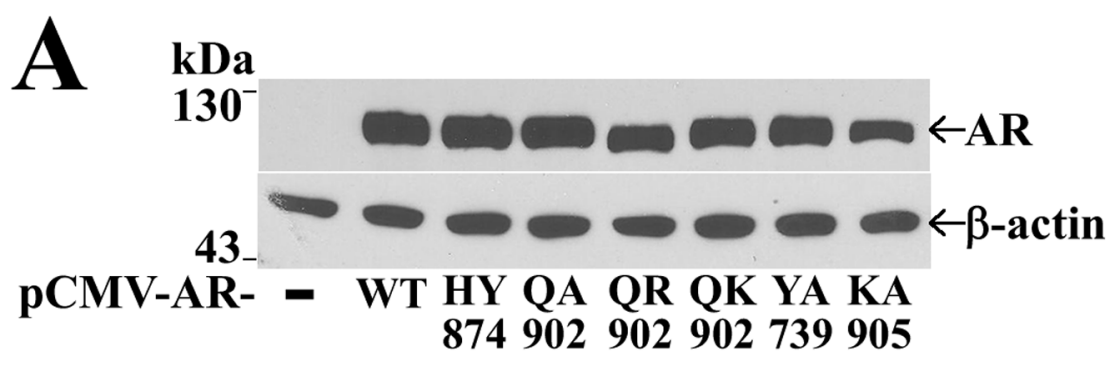

B

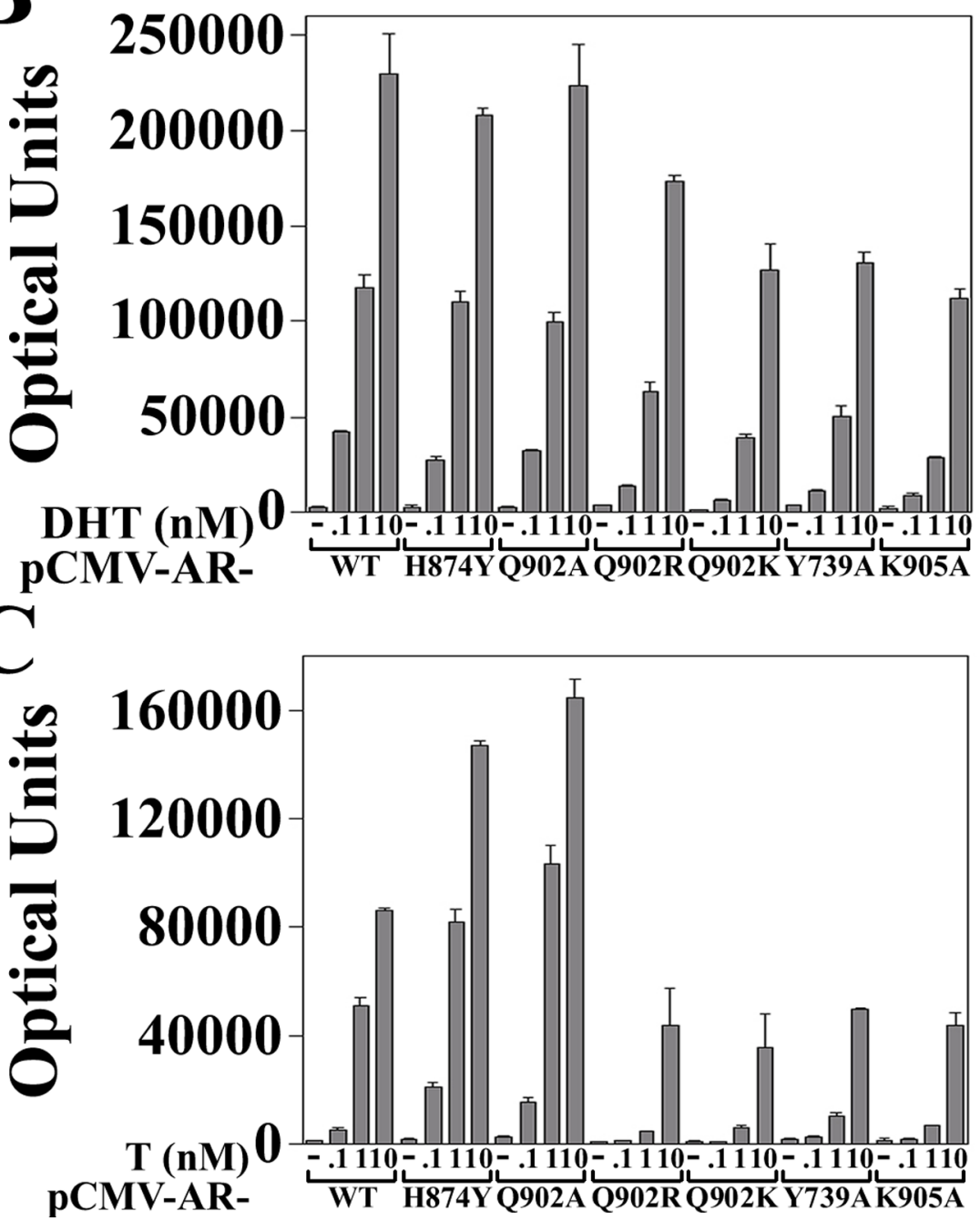

Figure 2. Modulation of AR transcriptional activity by LBD mutations flanking AF2 (A) COS cells were transfected with $5 \mu \mathrm{g}$ pCMV5 empty vector (-), pCMV-AR wild-type (WT) or the indicated mutant. Cell extracts ( $40 \mu \mathrm{g}$ protein/lane) were probed using AR52 and $\beta$-actin antibodies. (B, C) CV1 cells were transfected with $5 \mu \mathrm{g}$ PSA-Enh-Luc and 0.1 $\mu \mathrm{g}$ pCMV-AR WT, H874Y, Q902A, Q902R, Q902K, Y739A and K905A mutants analyzed by immunoblot in (A). Cells were incubated for $48 \mathrm{~h}$ in serum-free medium with and without $0.1,1$ and $10 \mathrm{nM}$ DHT (B) or testosterone (T) (C). 


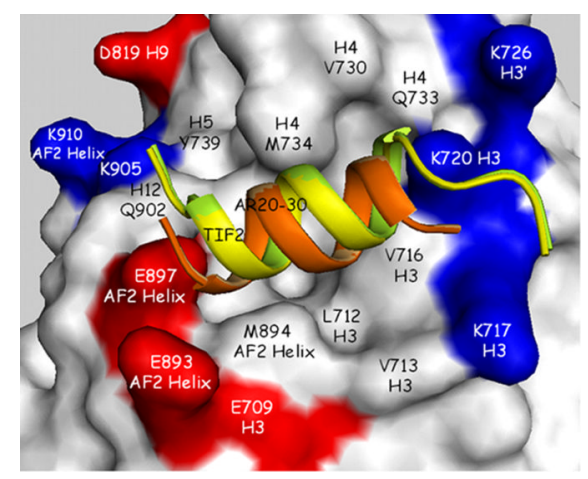

Figure 3. Superimposed surface representation of AR FXXLF and TIF2 LXXLL motif peptides bound to AF2 in the AR LBD-testosterone complex

AR-20-30 FXXLF (orange) and TIF2-740-753 LXXLL (yellow/green) motif peptides contact the AF2 surface flanked by AF2 helix 12 surface residues Glu-897 (AF2 E897, red) and helix 3 Lys-720 (H3 K720, blue) within clusters of charged residues (He and Wilson, 2003; He et al., 2004). $\mathrm{NH}_{2}$-terminal AR FXXLF motif residues 2-19 were predicted to extend toward AR LBD surface residues helix 12 Gln-902 (H12 Q902), helix 5 Tyr-739 (H5 Y739) and helix 12 Lys-905 (H12 K905). 


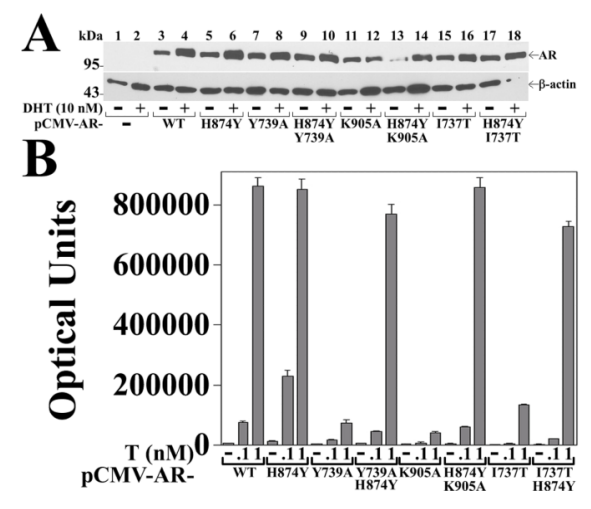

Figure 4. Functional rescue of destabilizing AR mutations by H874Y

(A) COS cells were transfected with $5 \mu \mathrm{g} / 10 \mathrm{~cm}$ dish of pCMV5 empty vector $(-), \mathrm{pCMV}$ AR wild-type (WT), H874Y, Y739A, H874Y/Y739A, K905A, H874Y/K905A, I737T or H874Y/I737T mutants. Cells were incubated for $24 \mathrm{~h}$ with and without $10 \mathrm{nM}$ DHT. The transblot containing $40 \mu \mathrm{g}$ cell extract protein/lane was probed using AR32 and $\beta$-actin antibodies. (B) HeLa cells were transfected with $0.25 \mu \mathrm{g}$ PSA-Enh-Luc and $0.01 \mu \mathrm{g}$ WT pCMV-AR or mutants in (A). Cells were incubated for $24 \mathrm{~h}$ in serum-free medium with and without 0.1 and $1 \mathrm{nM}$ testosterone $(\mathrm{T})$. 


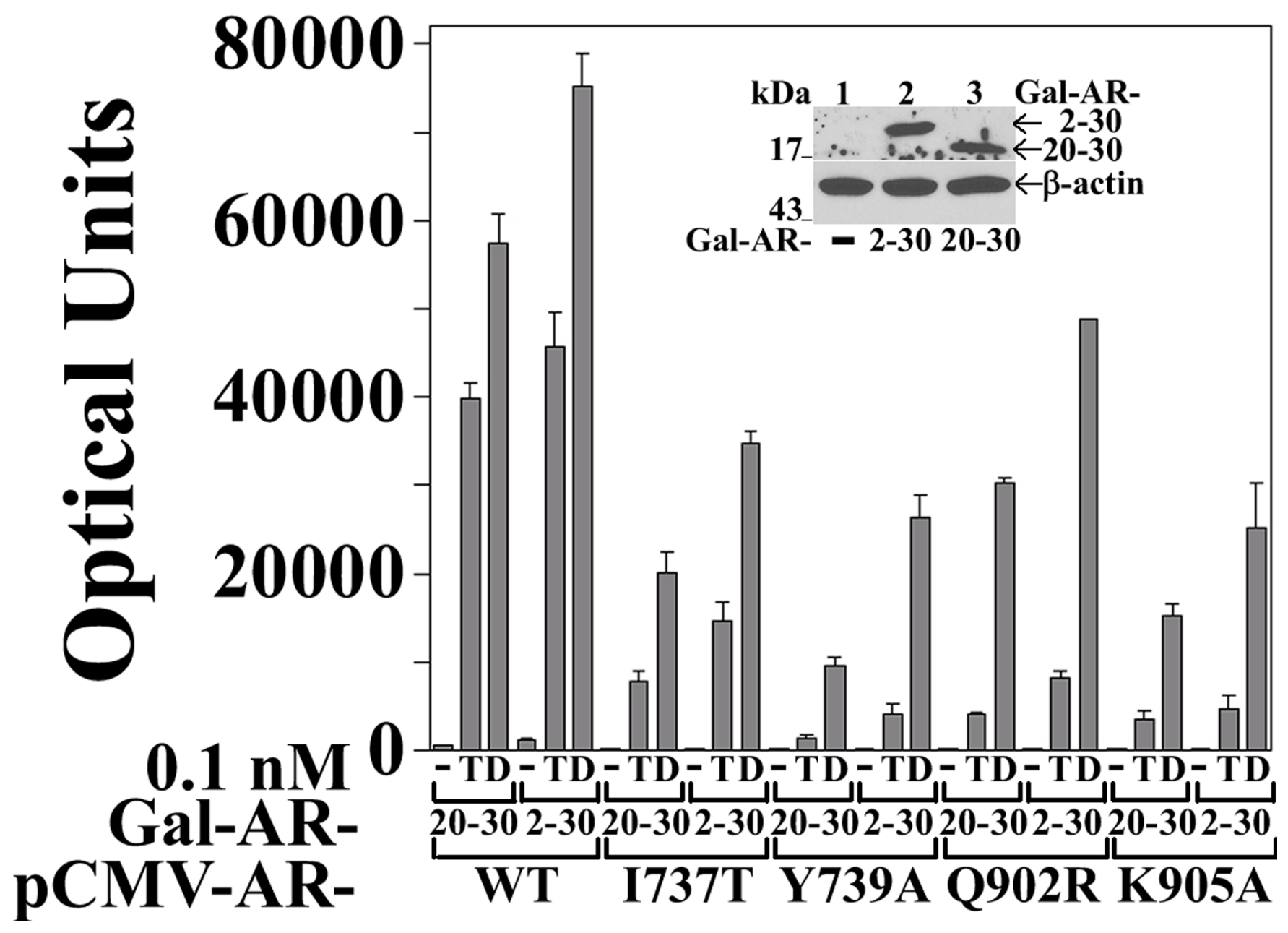

Figure 5. Amino acid residues $\mathrm{NH}_{2}$-terminal to the AR FXXLF motif enhance the AR N/C interaction

HeLa cells were transfected with $0.1 \mu \mathrm{g}$ 5XGAL4Luc3, 2 ng wild-type (WT) pCMV-AR, I737T, Y739A, Q902R or K905A mutant, and 0.05 $\mu$ g GAL-AR-2-30 or GAL-AR-20-30

FXXLF motif peptides. Cells were incubated in serum-free medium for $24 \mathrm{~h}$ with and without $0.1 \mathrm{nM}$ testosterone (T) or DHT (D). (Inset) COS cells were transfected with $10 \mu \mathrm{g}$ GALO empty vector (-), GAL-AR-2-30 or GAL-AR-20-30 FXXLF motif peptides. Cells were treated with $1 \mu \mathrm{M}$ MG132 for $24 \mathrm{~h}$ and again at $1 \mathrm{~h}$ prior to harvest. The transblot was probed using GAL and $\beta$-actin antibodies. 
.$\Xi$

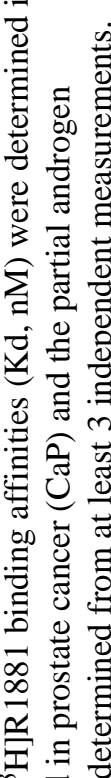

$\bar{I}: \Xi \frac{9}{8}$

药 里

를

- 苛芯

产

央

至苂

I

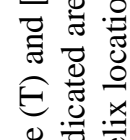

可

淧

要

产 $\sum^{\frac{0}{2}}$

要品

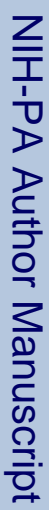

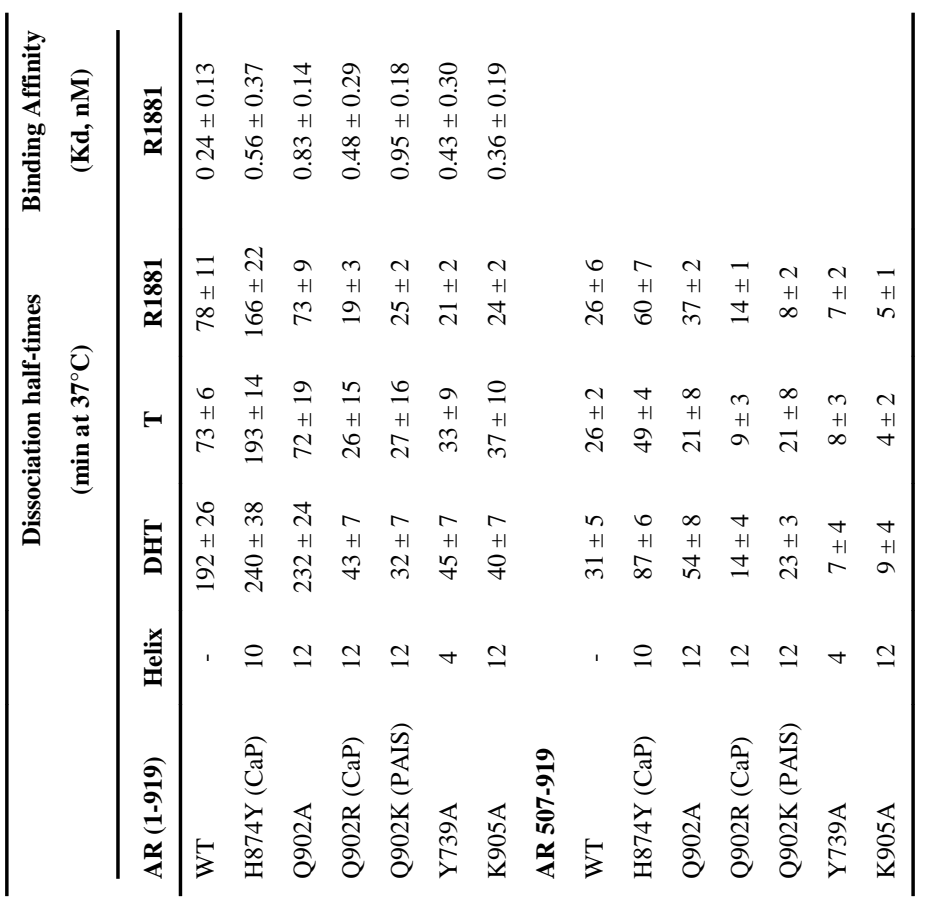

Mol Cell Endocrinol. Author manuscript; available in PMC 2013 January 30. 